\title{
ORGANIZATIONAL COMMITMENT AND TRUST AT WORK BY REMOTE EMPLOYEES
}

\author{
UDC: 005.96:331.101.3 \\ Original Scientific Paper \\ Srđana TABOROŠI ${ }^{1}$, Edin STRUKAN ${ }^{2}$, Jasmina POŠTIN ${ }^{3}$, Marko KONJIKUŠIĆ ${ }^{3}$, \\ Milan NIKOLIĆ \\ ${ }^{1}$ Republic of Serbia \\ ${ }^{2}$ Connecta d.o.o. 71000 Sarajevo, Dzemala Bijedica 172b, Bosnia and Herzegovina \\ ${ }^{3}$ Union - Nikola Tesla University, Belgrade, "Faculty of management", 21205 Sremski Karlovci, Njegoševa 1a, \\ Republic of Serbia \\ ${ }^{4}$ University of Novi Sad, Technical Faculty "Mihajlo Pupin”, 23000 Zrenjanin, Đure Đakovića bb, \\ Republic of Serbia \\ E-mail: mikaczr@sbb.rs
}

Paper received: 27.03.2020.; Paper accepted: 23.05.2019.

\begin{abstract}
This paper examines and analyzes the differences in organizational commitment and trust at work among conventionally employed and remote employees. Two additional control variables are introduced into the research: Gender and Age of the respondents. The survey included 265 respondents employed in organizations in Serbia (88.3\%) and surrounding countries (Bosnia and Herzegovina, Montenegro, Croatia). Remote employees show stronger organizational commitment and trust at work than conventional employees. This applies to the following four dimensions: organizational identification, faith in intentions of peers, confidence in actions of peers and confidence in actions of management. At the same time, the overall sample shows that the degree of engagement at work, as well as the degree of loyalty to the organization, does not depend on the way they work (conventionally or remotely). However, male teleworkers have a very low level of organizational loyalty and it will not be a problem for them to leave their current job if they are offered a better position at another organization. Older teleworkers exhibit statistically significantly greater confidence in management intentions than younger teleworkers. Leaders and managers in conventional organizations should be aware of the potential for employees to experience a decline in organizational identification and confidence in peers and managers. Organizations practicing teleworking must make sure that male teleworkers have low organizational loyalty and can easily leave their current job.
\end{abstract}

Key words: Organizational commitment; Trust at work; Employees; Gender; Age.

\section{INTRODUCTION}

The first forms of remote work appeared in the United States in the 1970s, in the form of telephone customer support. Then this method of work was called telecommuting. Shortly afterwards, in the early 1990s, this type of work attracted more and more attention and the motto "Work is something you do, not something you travel to" became part of popular culture. The next major step in teleworking is the beginning of the 21 st century, with an extremely large increase in the use of information technology, and when a large number of IT companies are beginning to use teleworking as a resource due to cost savings. In this way, companies were able to hire workers in other parts of the world or allow existing employees to work outside the offices. This method of work, in addition to saving on the cost of transportation, owning and maintaining offices, then the ability to hire cheaper labor, also has a positive impact on the environment. For example, federal agencies estimated that if at least $40 \%$ of the U.S. population worked part-time by the end of 2020, it would have the following positive effects: saving $37 \%$ of oil imports, environmental impact would reduce by 9 million cars, energy that would be conserved equals twice the amount of energy 
produced by the US from sustainable sources, (Lister, Harnish, \& Nilles, 2009).

According to Pratt (1999), a 1999 International Telework Association and Council survey shows that 19.6 million Americans already worked remotely. This number has continued to grow due to various factors such as technology advances, sociological trends, the need for additional jobs due to economic crises, and the need for single parents to spend more time at home. The pressure for greater need for teleworkers is not one-sided: companies also wanted to reduce costs, reduce their negative impact on the environment, and increase their ability for quality recruiting.

Employment agencies in the UK have reported that around $85 \%$ of job seekers would have stayed at the previous job if teleworking was an option, (Twentyman, 2010). This is important information for companies in industries that can effortlessly employ remote workforce. Also, high levels of job satisfaction have been observed in teleworkers, (Madsen, 2011), and as Wheatley (2012) reports, people who work from home have an extremely high level of job satisfaction. This is explained by the flexibility of working hours and saving time when commuting. Also, this study finds that the "extra" hours available for remote workforce are not only used for rest, but also for housework, training or hobbies, further enhancing employee loyalty. The study also points out that there are positive factors for employers as well.

The very definition of telework is still a matter of debate, which still does not provide a clear answer to this question. Morgan (2004) describes teleworking as work performed using telecommunication devices. The term "remote worker" itself basically means a person who, under flexible conditions, works in different locations. This means that business tasks can be done anytime, from anywhere in the world. Regardless of the possible weaknesses in the theoretical basis, teleworking is becoming, and is, largely, one of the most significant contemporary challenges for researchers in the field of organizational behavior, (Janicijevic, 2008; Robbins, Judge, 2009). Accordingly, there are a considerable number of scientific papers in this field. Given the current global circumstances caused by the pandemic due to coronavirus disease (COVID-19), it is quite expected that research on the organizational, social and psychological aspects of teleworking is gaining in importance.
Early research shows that employees with certain demographic similarities are more motivated to work remotely. Groups such as marriages with both working partners, women, couples with young children, single mothers and higher educated people have specific reasons for being motivated for such work, (Mokhtarian, Bagley, \& Salomon, 1998; Pratt, 1999). These studies show that women in the United States show greater job satisfaction than men who work remotely.

Several studies have addressed job satisfaction with teleworkers, and an increase in this aspect of work is observed, relative to conventionally employed employees, (De Lay, 1995; Pratt, 1999). Coveyduck (1997) points out that, in addition to high job satisfaction, teleworkers also have greater autonomy in performing work tasks, greater commitment to the company they work for, and feel greater support from the company. Presumably, this is due to the fact that the managers of teleworkers need to be more frequently in contact with their employees.

Likewise, many studies show an increase in productivity and performance when employees work remotely, (Bernardino, 1996; Gainey, Kelley, \& Hill, 1999; Ross, 1990). Pratt's work shows that people who have the ability to work remotely experience the same or increased level of productivity when using that opportunity, (Pratt, 1999).

In this paper, the results of the research are presented, which aims to examine and analyze differences in organizational commitment dimensions and trust at work dimensions, among conventionally employed and remotely employed. Two additional control variables are introduced into the research: Gender and Age of the respondents. Accordingly, the survey includes people who are employed on a conventional basis and on a remote basis. Examinees are mostly employed by organizations in Serbia (88.3\%), while others come from organizations from countries in the region (Bosnia and Herzegovina, Montenegro, Croatia). Based on the results gained and the comparisons made, guidelines for leaders and managers from conventional organizations are defined, as well as for leaders and managers from organizations that prefer teleworking. These guidelines indicate the current state of affairs in the sphere of the influence of working methods (conventional and remote) on organizational 
commitment and confidence at work among employees, as well as possible directions of action in order to improve the observed performance, from the aspect of the way a particular organization works.

\section{THEORY AND HYPOTHESIS}

If differences in conventional and teleworking are observed, it can be assumed that teleworkers have lower values of organizational commitment and trust at work because they simply do not directly interact with their colleagues and do not spend physical time with them. In contrast, most studies show the exact opposite. In addition to increased productivity and job satisfaction, organizational commitment is one of the most widely recognized benefits of working remotely.

This is especially true for remote employees who have families of their own. This way of working enables them to timely act on exceptional occasions, and this creates strong emotional bonds, (Ellison, 1999). Exceptional circumstances, which are mainly related to the unfavorable health of the employees themselves or their family members, generally result in a deterioration of commitment, but in the case of remote employees, negative personal events do not diminish organizational commitment. According to Pratt (1999), teleworking also enables the recruitment of employees who belong to new social groups and who, due to their condition, have not been able to successfully participate in the labor market before. These groups often include people with disabilities, careers of a family member or families with many children. It is precisely with such employees that the organizational commitment values are very high.

It is a common assumption that remote employees have a better work-life balance. Although teleworkers generally spend more time doing their jobs, they do so at a time that suits them and that flexibility contributes to their job satisfaction. What contributes to this is that the balance of work and private life not only indicates the number of hours spent at work, but also the absence of different stress factors: inadequate schedules, quality of relations with superiors, independence at work, childcare and the like. A study (De Lay, 1995) shows that men have a lower level of balance between private and business life, which may cause a lower organizational commitment. On the other hand, women, especially those with young children, show a high degree of commitment. This is probably due to the continued pressure from society that it is the woman who cares about responsibilities around the home and children.

Socializing with colleagues at work can result in the support of co-workers, the generation of new ideas, or even an increase in effectiveness. Due to the "isolation", teleworkers do not have these benefits, however, this does not mean that they feel less connected to the company they work for. Gainey, Kelley, and Hill (1999) show that personal sense of comfort, satisfaction, and commitment contributes to higher values of organizational commitment. This has especially been shown in people whose occupations are related to communication, such as support services, which are common remote jobs in the United States. This may also mean that communication is something that is important to remote employees.

Later research (Dimitrova, 2003) shows that remote employees, with a pronounced autonomy, need less supervision by their superiors, but all teleworkers have an important sense of trust in them. This study concludes that a remote employee values a very helpful environment that is willing to help them, but they show less value in socialization with colleagues. More frequent contact with supervisors is sufficient to motivate and trust remote workers. This may simply be due to the fact that the amount of work that one person does has increased, and that people feel that socialization is tiring them and, in a way, distracting them from work tasks.

There are several factors that are key to successful remote work, such as: quality management and support systems, formal and clear measures and training, and the use of formal and informal communication, (Kowalski, \& Swanson, 2005). If all the factors are at a satisfactory level, and if the tasks are clear, remote employees have high confidence in the management of their company. These are universal parameters, which show positive results for conventionally employed people as well, but are especially important in this innovative method because remote employees often never come into personal contact with their colleagues and managers. Due to the inability to properly recognize non-verbal communication as well as cultural differences, clear communication is of utmost importance. 
With the accelerating growth of the IT industry in recent decades, the number of teleworkers in the United States has grown rapidly. As North America is known as a culture that values individualism and masculine values highly (Janicijevic, 2008; Robbins, Judge, 2009), research has been done on how to show respect for remote employees in a best way, since personal contact is very rare or does not exist, (White, 2018). The survey was extensive and was carried out in 20142018. One of the managerial shortcomings of teleworking is that most respondents (teleworkers) express the need for validation, which is most quickly achieved through spending free time with colleagues, working together on larger projects and relaxed chatting in breaks. Both oral and written praise are certainly highly ranked in both employee groups (conventional and remote), but remote employees value this form of validation less. This implies that remote employees have a greater need for communication: this is something they still lack.

Research conducted in Italy (Erricheiello, Pianesse, 2019) examines how to design coworking spaces for teleworkers (coworking spaces are business spaces that allow digital workers to rent a physical office or desk in a group office). The respondents were users of the coworking space. The study identifies specific recommendations and procedures that the authors believe would mitigate sudden changes in the behavior of users of these spaces and help overcome some of the challenges that remote employees face.

Another of the "dangers" that remote employees face is communication through digital media. Although innovative technologies have enabled the emergence of telework, they also carry dangers. Social networks and digital communication processes are also changing the way business communication is conducted. These are basic tools for remote employees, however, they also cause some undesirable effects such as distraction and procrastination. Regarding this, a survey conducted in France (Bowen, \& Pennaforte, 2017) confirms that social networks and digital communication tools are indeed a new challenge among teleworkers. This impact must be considered as a threat to the productivity of teleworkers, who are highly susceptible to such negative occurrences.

Due to the use of digital technologies, communication becomes less formal and hierarchical, relationships weaken, which often leads to increased trust among employees, and due to the lack of face-to-face encounters, the hierarchy weakens naturally, (Hoch, \& Kozlowski, 2014). This research concludes that non-business-oriented communication between remote employees is desirable, and that such communication produces the best results. High quality LMX and frequent informal support are recommended.

Contrary to previous statements, there are some research that conclude that remote employees may have lower performance. For example, research in the Netherlands (de Vries, Tummers, \& Bekkers, 2018), shows a significant decline in organizational commitment in public sector teleworkers. Also, it has been observed that effective LMX mechanisms attenuate this negative impact.

Considering that two basic groups of respondents (conventionally employed and teleworkers) are observed in the paper, with two control variables (Gender and Age) introduced, in this paper, nine hypotheses are set:

H1: There is a statistically significant difference in the average scores of individual organizational commitment dimensions and trust at work dimensions, for conventionally employed and remote employees.

$H 2$ : There is a statistically significant difference in the average scores of individual organizational commitment dimensions and trust at work dimensions, for conventionally employed men and conventionally employed women.

H3: There is a statistically significant difference in the average scores of individual organizational commitment dimensions and trust at work dimensions, for both male and female employees.

H4: There is a statistically significant difference in the average scores of individual organizational commitment dimensions and trust at work dimensions, for men employed conventionally and men employed remotely.

H5: There is a statistically significant difference in the average scores of individual organizational commitment dimensions and trust at work dimensions, for women employed conventionally and women employed remotely.

H6: There is a statistically significant difference in the average scores of individual organizational commitment dimensions and 
trust at work dimensions, for conventionally employed younger respondents and conventionally employed older respondents.

H7: There is a statistically significant difference in the average scores of individual organizational commitment dimensions and trust at work dimensions, for junior employees and long-term employees.

H8: There is a statistically significant difference in the average scores of individual organizational commitment dimensions and trust at work dimensions, for younger

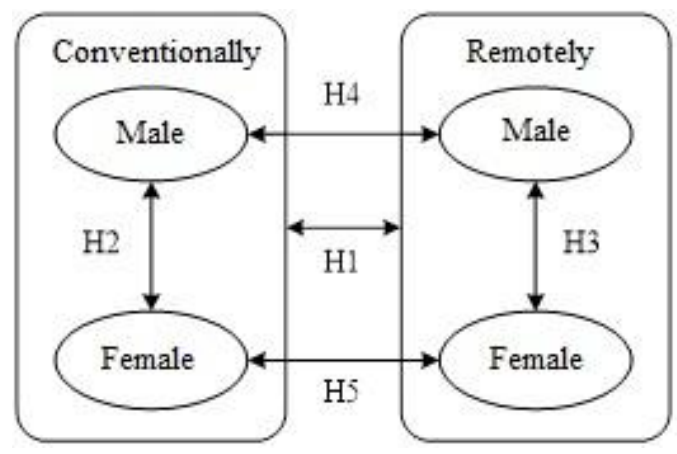

Figure 1: Graphical representation of the hypotheses respondents employed conventionally and younger respondents employed remotely.

H9: There is a statistically significant difference in the average scores of individual organizational commitment dimensions and trust at work dimensions, for older respondents employed conventionally and older respondents employed remotely.

The hypotheses are presented graphically in order to facilitate follow up (Figure 1).

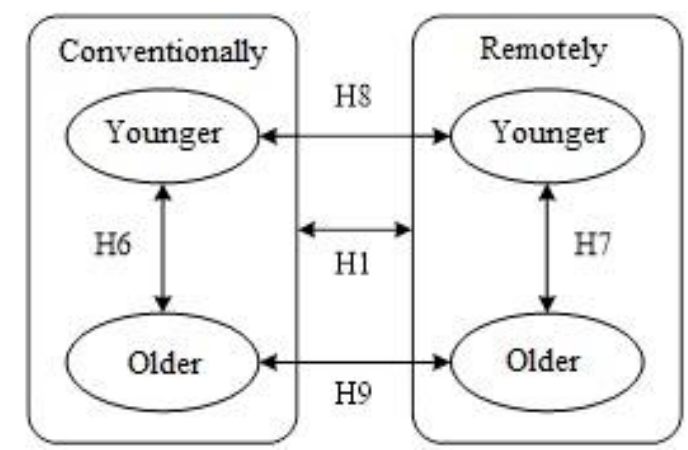

(88.3\%). The survey was conducted anonymously. Respondents are conventionally and remotely employed. A total of 265 valid questionnaires were collected.

Organizational commitment. Organizational commitment was measured by an instrument developed by Cook and Wall (1980). The instrument has 9 items and 3 dimensions that assess organizational identification, organizational involvement, and organizational loyalty of employees. The answers were rated 1-7, with 1 being strongly disagreeing and 7 being completely agreeing.

Trust at work. Interpersonal trust at work was measured by an instrument developed by Cook and Wall (1980). The instrument has 12 items and measures faith in the intentions and confidence in the actions of colleagues and management across 4 dimensions. The answers were rated 1-7, with 1 being strongly disagreeing and 7 being completely agreeing.

\section{Participants}

The survey was conducted with the respondents, who are employed in organizations in Serbia and surrounding countries (Bosnia and Herzegovina, Montenegro, Croatia). However, the sample is dominated by employees in organizations in Serbia
For this paper, the following sample characteristics are particularly relevant:

- The sample consisted of $111 \quad(41.9 \%)$ conventionally employed and 154 (58.1\%) remotely employees.

- There were 67 (25.3\%) men and 198 (74.7\%) women in the sample.

- There were $143(54.0 \%)$ younger respondents and $122(46.0 \%)$ older respondents in the sample. The sample included employees between 19 and 62 years old, but the majority of respondents were younger than 35 years. As a result, younger respondents were classified as respondents up to 31 years of age, while older respondents were classified as those aged 32 and older. 


\section{RESULTS}

\section{Descriptive statistics}

Descriptive statistics for organizational commitment dimensions and trust at work dimensions are given in Table 1 (dimensions names, abbreviations for dimensions, mean values, standard deviation and Cronbach's alpha for dimensions). Cronbach's alpha values range from 0.711 to 0.948 . The results in Table 1 apply to the total sample (conventionally employed and remotely employed together).

Table 1: Descriptive statistics for organizational commitment dimensions and trust at work dimensions (total sample)

\begin{tabular}{|l|c|c|c|c|c|c|c|}
\hline \multicolumn{1}{|c|}{ Dimensions } & Abbr. & N & Min & Max & Mean & Std. Dev. & $\begin{array}{c}\text { Cronbach's } \\
\text { Alpha }\end{array}$ \\
\hline Organizational identification & OCM1 & 265 & 1.000 & 7.000 & 4.69308 & 1.704289 & 0.863 \\
\hline Organizational involvement & OCM2 & 265 & 1.000 & 7.000 & 5.26792 & 1.487857 & 0.843 \\
\hline Organizational loyalty & OCM3 & 265 & 1.000 & 7.000 & 3.41887 & 1.577481 & 0.711 \\
\hline Faith in intentions of Peers & TW1 & 265 & 1.000 & 7.000 & 5.20503 & 1.541341 & 0.906 \\
\hline Faith in intentions of Management & TW2 & 265 & 1.000 & 7.000 & 4.03145 & 1.891261 & 0.914 \\
\hline Confidence in actions of Peers & TW3 & 265 & 1.000 & 7.000 & 4.95472 & 1.488043 & 0.927 \\
\hline Confidence in actions of Management & TW4 & 265 & 1.000 & 7.000 & 4.00252 & 1.862711 & 0.948 \\
\hline Valid N (listwise) & & 265 & & & & & \\
\hline
\end{tabular}

\section{T-test}

A t-test was used to compare average scores of organizational commitment dimensions and trust at work dimensions. The results of the t-test are presented in five Tables (Table 2, Table 3, Table 4, Table 5 and Table 6). In these tables, results with a statistically significant difference in the mean ratings of the observed dimensions are shown in bold font.

The results of the t-test over the average organizational commitment dimensions and trust at work dimensions, for conventionally employed and teleworkers, are given in Table 2.

The results of the t-test over average ratings of organizational commitment dimensions and trust at work dimensions, for conventionally employed men and women, as well as for remotely employed men and women, are given in Table 3.
The results of the t-test over average ratings of organizational commitment dimensions and trust at work dimensions, for men employed conventionally and remotely, and for women employed conventionally and remotely, are given in Table 4.

The results of the t-test over average ratings of organizational commitment dimensions and trust at work dimensions, for conventionally employed younger and older respondents, as well as for remotely employed older and younger respondents, are given in Table 5.

The results of the t-test over average ratings of organizational commitment dimensions and trust at work dimensions, for younger respondents employed conventionally and remotely, as well as for older respondents employed conventionally and remotely, are given in Table 6. 
Table 2: The results of the t-test over the average organizational commitment dimensions and trust at work dimensions, for conventionally and remotely employed

\begin{tabular}{|c|c|c|c|c|c|c|c|c|c|c|}
\hline \multirow[t]{2}{*}{ Dim. } & \multirow{2}{*}{$\begin{array}{c}\text { Type of } \\
\text { employment }\end{array}$} & \multirow[t]{2}{*}{$\mathrm{N}$} & \multirow[t]{2}{*}{ Mean } & \multirow{2}{*}{$\begin{array}{c}\text { Std. } \\
\text { Deviation }\end{array}$} & \multirow{2}{*}{$\begin{array}{c}\text { Std. Error } \\
\text { Mean }\end{array}$} & \multicolumn{2}{|c|}{$\begin{array}{c}\text { Levene's Test } \\
\text { for Equality of } \\
\text { Variances }\end{array}$} & \multicolumn{3}{|c|}{ t-test for Equality of Means } \\
\hline & & & & & & $\mathrm{F}$ & Sig. & $\mathrm{t}$ & $\mathrm{df}$ & $\begin{array}{c}\text { Sig. } \\
\text { (2-tailed) }\end{array}$ \\
\hline \multirow{2}{*}{ OCM1 } & Convent. & 111 & 4.38739 & 1.797608 & .170621 & \multirow[t]{2}{*}{3.114} & \multirow[t]{2}{*}{.079} & -2.504 & 263 & .013 \\
\hline & Remotely & 154 & 4.91342 & 1.603738 & .129233 & & & -2.458 & 220.29 & .015 \\
\hline \multirow{2}{*}{ OCM2 } & Convent. & 111 & 5.32432 & 1.548189 & .146948 & \multirow[t]{2}{*}{.658} & \multirow[t]{2}{*}{.418} & .523 & 263 & .601 \\
\hline & Remotely & 154 & 5.22727 & 1.446557 & .116567 & & & .517 & 227.29 & .605 \\
\hline \multirow{2}{*}{ OCM3 } & Convent. & 111 & 3.51051 & 1.650112 & .156622 & \multirow[t]{2}{*}{.884} & \multirow[t]{2}{*}{.348} & .802 & 263 & .423 \\
\hline & Remotely & 154 & 3.35281 & 1.525021 & .122890 & & & .792 & 225.65 & .429 \\
\hline \multirow{2}{*}{ TW1 } & Convent. & 111 & 4.86486 & 1.652289 & .156828 & \multirow[t]{2}{*}{5.078} & \multirow[t]{2}{*}{.025} & -3.099 & 263 & .002 \\
\hline & Remotely & 154 & 5.45022 & 1.411403 & .113734 & & & -3.022 & 213.64 & .003 \\
\hline \multirow{2}{*}{ TW2 } & Convent. & 111 & 3.83183 & 1.758600 & .166919 & \multirow[t]{2}{*}{2.783} & \multirow[t]{2}{*}{.096} & -1.462 & 263 & .145 \\
\hline & Remotely & 154 & 4.17532 & 1.974492 & .159109 & & & -1.490 & 251.46 & .138 \\
\hline \multirow{2}{*}{ TW3 } & Convent. & 111 & 4.73273 & 1.515456 & .143841 & \multirow[t]{2}{*}{1.426} & \multirow[t]{2}{*}{.234} & -2.075 & 263 & .039 \\
\hline & Remotely & 154 & 5.11472 & 1.451906 & .116998 & & & -2.060 & 231.00 & .041 \\
\hline \multirow{2}{*}{ TW4 } & Convent. & 111 & 3.61562 & 1.749573 & .166062 & \multirow[t]{2}{*}{1.373} & \multirow[t]{2}{*}{.242} & -2.911 & 263 & .004 \\
\hline & Remotely & 154 & 4.28139 & 1.897187 & .152880 & & & -2.950 & 247.60 & .003 \\
\hline
\end{tabular}

Table 3: T-test for conventionally employed men and women, and for remotely employed men and women

\begin{tabular}{|c|c|c|c|c|c|c|c|c|c|c|c|}
\hline \multirow{2}{*}{$\begin{array}{c}\text { Type } \\
\text { of empl. }\end{array}$} & \multirow[t]{2}{*}{ Dim. } & \multirow[t]{2}{*}{ Gend. } & \multirow[t]{2}{*}{$\mathrm{N}$} & \multirow[t]{2}{*}{ Mean } & \multirow{2}{*}{$\begin{array}{c}\text { Std. } \\
\text { Deviation }\end{array}$} & \multirow{2}{*}{$\begin{array}{l}\text { Std. Error } \\
\text { Mean }\end{array}$} & \multicolumn{2}{|c|}{$\begin{array}{c}\text { Levene's Test for } \\
\text { Equality of } \\
\text { Variances }\end{array}$} & \multicolumn{3}{|c|}{ t-test for Equality of Means } \\
\hline & & & & & & & $\mathrm{F}$ & Sig. & $\mathrm{t}$ & df & $\begin{array}{c}\text { Sig. } \\
\text { (2-tailed) }\end{array}$ \\
\hline \multirow{14}{*}{ Conv. } & \multirow{2}{*}{ OCM1 } & Male & 23 & 4.85507 & 1.722771 & .359223 & \multirow[t]{2}{*}{.014} & \multirow[t]{2}{*}{.905} & 1.408 & 109 & .162 \\
\hline & & Fem. & 88 & 4.26515 & 1.806162 & .192537 & & & 1.447 & 35.711 & .157 \\
\hline & \multirow{2}{*}{$\mathrm{OCM} 2$} & Male & 23 & 5.42029 & 1.168688 & .243688 & \multirow[t]{2}{*}{1.581} & \multirow[t]{2}{*}{.211} & .333 & 109 & .740 \\
\hline & & Fem. & 88 & 5.29924 & 1.637710 & .174580 & & & .404 & 47.232 & .688 \\
\hline & \multirow{2}{*}{ OCM3 } & Male & 23 & 4.07246 & 1.466655 & .305819 & \multirow[t]{2}{*}{.562} & \multirow[t]{2}{*}{.455} & 1.855 & 109 & .066 \\
\hline & & Fem. & 88 & 3.36364 & 1.671362 & .178168 & & & 2.003 & 38.351 & .052 \\
\hline & \multirow{2}{*}{ TW1 } & Male & 23 & 5.27536 & 1.555869 & .324421 & \multirow[t]{2}{*}{.109} & \multirow[t]{2}{*}{.741} & 1.343 & 109 & .182 \\
\hline & & Fem. & 88 & 4.75758 & 1.668373 & .177849 & & & 1.400 & 36.379 & .170 \\
\hline & \multirow{2}{*}{ TW2 } & Male & 23 & 4.14493 & 1.791749 & .373605 & \multirow[t]{2}{*}{.000} & \multirow[t]{2}{*}{.986} & .959 & 109 & .340 \\
\hline & & Fem. & 88 & 3.75000 & 1.750935 & .186650 & & & .946 & 33.820 & .351 \\
\hline & \multirow{2}{*}{ TW3 } & Male & 23 & 4.86957 & 1.742920 & .363424 & \multirow[t]{2}{*}{2.461} & \multirow[t]{2}{*}{.120} & .485 & 109 & .629 \\
\hline & & Fem. & 88 & 4.69697 & 1.459226 & .155554 & & & .437 & 30.540 & .665 \\
\hline & TW4 & Male & 23 & 3.81159 & 1.811373 & .377697 & .001 & .973 & .602 & 109 & .549 \\
\hline & 164 & Fem. & 88 & 3.56439 & 1.740039 & .185489 & & & .587 & 33.400 & .561 \\
\hline & OCM1 & Male & 44 & 4.71212 & 1.582512 & .238573 & .000 & .985 & -.985 & 152 & .326 \\
\hline & UCIVI & Fem. & 110 & 4.99394 & 1.612250 & .153722 & & & -.993 & 80.634 & .324 \\
\hline & OCM2 & Male & 44 & 4.93182 & 1.562777 & .235597 & 1.757 & .187 & -1.611 & 152 & .109 \\
\hline & UCIVI & Fem. & 110 & 5.34545 & 1.387234 & .132268 & & & -1.531 & 71.573 & .130 \\
\hline & OCM3 & Male & 44 & 2.92424 & 1.674962 & .252510 & 2.468 & .118 & -2.234 & 152 & .027 \\
\hline & U CIVIS & Fem. & 110 & 3.52424 & 1.433158 & .136646 & & & -2.090 & 69.520 & .040 \\
\hline Rem & TW1 & Male & 44 & 5.05303 & 1.737180 & .261890 & 7.407 & .007 & -2.237 & 152 & .027 \\
\hline Kem. & $1 \mathrm{WI}$ & Fem. & 110 & 5.60909 & 1.231476 & .117417 & & & -1.937 & 61.051 & .057 \\
\hline & TW2 & Male & 44 & 3.71212 & 1.937780 & .292131 & .119 & .731 & -1.856 & 152 & .065 \\
\hline & $1 \mathrm{WZ}$ & Fem. & 110 & 4.36061 & 1.967178 & .187563 & & & -1.868 & 80.371 & .065 \\
\hline & TW3 & Male & 44 & 5.00758 & 1.603434 & .241727 & 1.595 & .209 & -.578 & 152 & .564 \\
\hline & 125 & Fem. & 110 & 5.15758 & 1.392209 & .132742 & & & -.544 & 70.321 & .588 \\
\hline & & Male & 44 & 4.06061 & 1.761302 & .265526 & 1.116 & .292 & -.913 & 152 & .363 \\
\hline & 164 & Fem. & 110 & 4.36970 & 1.949592 & .185886 & & & -.954 & 87.213 & .343 \\
\hline
\end{tabular}


Table 4: T-test for men employed conventionally and remotely, and for women employed conventionally and remotely

\begin{tabular}{|c|c|c|c|c|c|c|c|c|c|c|c|}
\hline \multirow[t]{2}{*}{ Gender } & \multirow[t]{2}{*}{ Dim. } & \multirow{2}{*}{$\begin{array}{l}\text { Type } \\
\text { of } \\
\text { empl. }\end{array}$} & \multirow[t]{2}{*}{$\mathrm{N}$} & \multirow[t]{2}{*}{ Mean } & \multirow{2}{*}{$\begin{array}{c}\text { Std. } \\
\text { Deviation }\end{array}$} & \multirow{2}{*}{$\begin{array}{l}\text { Std. Error } \\
\text { Mean }\end{array}$} & \multicolumn{2}{|c|}{$\begin{array}{l}\text { Levene's Test } \\
\text { for Equality of } \\
\text { Variances } \\
\end{array}$} & \multicolumn{3}{|c|}{ t-test for Equality of Means } \\
\hline & & & & & & & F & Sig. & $\mathrm{t}$ & $\mathrm{df}$ & $\begin{array}{c}\text { Sig. } \\
(2 \text {-tailed) }\end{array}$ \\
\hline \multirow{14}{*}{ Male } & \multirow{2}{*}{ OCM1 } & Convent. & 23 & 4.85507 & 1.722771 & .359223 & \multirow[t]{2}{*}{1.263} & \multirow[t]{2}{*}{.265} & .341 & 65 & .735 \\
\hline & & Remotely & 44 & 4.71212 & 1.582512 & .238573 & & & .331 & 41.552 & .742 \\
\hline & \multirow[b]{2}{*}{ OCM2 } & Convent. & 23 & 5.42029 & 1.168688 & .243688 & \multirow[t]{2}{*}{1.550} & \multirow[t]{2}{*}{.218} & 1.317 & 65 & .192 \\
\hline & & Remotely & 44 & 4.93182 & 1.562777 & .235597 & & & 1.441 & 56.909 & .155 \\
\hline & \multirow{2}{*}{ OCM3 } & Convent. & 23 & 4.07246 & 1.466655 & .305819 & \multirow[t]{2}{*}{.717} & \multirow[t]{2}{*}{.400} & 2.776 & 65 & .007 \\
\hline & & Remotely & 44 & 2.92424 & 1.674962 & .252510 & & & 2.895 & 50.269 & .006 \\
\hline & \multirow{2}{*}{ TW1 } & Convent. & 23 & 5.27536 & 1.555869 & .324421 & \multirow[t]{2}{*}{.035} & \multirow[t]{2}{*}{.851} & .515 & 65 & .608 \\
\hline & & Remotely & 44 & 5.05303 & 1.737180 & .261890 & & & .533 & 49.303 & .596 \\
\hline & \multirow{2}{*}{ TW2 } & Convent. & 23 & 4.14493 & 1.791749 & .373605 & \multirow[t]{2}{*}{.205} & \multirow[t]{2}{*}{.652} & .890 & 65 & .377 \\
\hline & & Remotely & 44 & 3.71212 & 1.937780 & .292131 & & & .913 & 47.954 & .366 \\
\hline & \multirow{2}{*}{ TW3 } & Convent. & 23 & 4.86957 & 1.742920 & .363424 & \multirow[t]{2}{*}{.964} & \multirow[t]{2}{*}{.330} & -.325 & 65 & .746 \\
\hline & & Remotely & 44 & 5.00758 & 1.603434 & .241727 & & & -.316 & 41.606 & .753 \\
\hline & TWU & Convent. & 23 & 3.81159 & 1.811373 & .377697 & .003 & .957 & -.544 & 65 & .588 \\
\hline & $1 \mathrm{~W} 4$ & Remotely & 44 & 4.06061 & 1.761302 & .265526 & & & -.539 & 43.663 & .592 \\
\hline & OCM1 & Convent. & 88 & 4.26515 & 1.806162 & .192537 & 2.328 & .129 & -2.996 & 196 & .003 \\
\hline & OCVI & Remotely & 110 & 4.99394 & 1.612250 & .153722 & & & -2.958 & 176.140 & .004 \\
\hline & OCM & Convent. & 88 & 5.29924 & 1.637710 & .174580 & 2.925 & .089 & -.215 & 196 & .830 \\
\hline & UCM2 & Remotely & 110 & 5.34545 & 1.387234 & .132268 & & & -.211 & 170.661 & .833 \\
\hline & & Convent. & 88 & 3.36364 & 1.671362 & .178168 & 2.776 & .097 & -.728 & 196 & .468 \\
\hline & OCM3 & Remotely & 110 & 3.52424 & 1.433158 & .136646 & & & -.715 & 171.962 & .475 \\
\hline Female & TW1 & Convent. & 88 & 4.75758 & 1.668373 & .177849 & 9.850 & .002 & -4.129 & 196 & .000 \\
\hline remale & $1 \mathrm{WI}$ & Remotely & 110 & 5.60909 & 1.231476 & .117417 & & & -3.996 & 155.752 & .000 \\
\hline & TW2 & Convent. & 88 & 3.75000 & 1.750935 & .186650 & 1.784 & .183 & -2.278 & 196 & .024 \\
\hline & $1 W 2$ & Remotely & 110 & 4.36061 & 1.967178 & .187563 & & & -2.308 & 193.738 & .022 \\
\hline & & Convent. & 88 & 4.69697 & 1.459226 & .155554 & 1.177 & .279 & -2.264 & 196 & .025 \\
\hline & TW3 & Remotely & 110 & 5.15758 & 1.392209 & .132742 & & & -2.252 & 182.569 & .025 \\
\hline & & Convent. & 88 & 3.56439 & 1.740039 & .185489 & 1.721 & .191 & $\begin{array}{l}-3.028 \\
\end{array}$ & 196 & .003 \\
\hline & 164 & Remotely & 110 & 4.36970 & 1.949592 & .185886 & & & -3.067 & 193.623 & .002 \\
\hline
\end{tabular}

Table 5: T-test for conventionally employed younger and older respondents, and for remotely employed older and younger respondents

\begin{tabular}{|c|c|c|c|c|c|c|c|c|c|c|c|}
\hline \multirow{2}{*}{$\begin{array}{l}\text { Type } \\
\text { of } \\
\text { empl. }\end{array}$} & \multirow[t]{2}{*}{ Dim. } & \multirow[t]{2}{*}{ Age } & \multirow[t]{2}{*}{$\mathrm{N}$} & \multirow[t]{2}{*}{ Mean } & \multirow{2}{*}{$\begin{array}{c}\text { Std. } \\
\text { Deviation }\end{array}$} & \multirow{2}{*}{$\begin{array}{l}\text { Std. Error } \\
\text { Mean }\end{array}$} & \multicolumn{2}{|c|}{$\begin{array}{c}\text { Levene's Test for } \\
\text { Equality of } \\
\text { Variances }\end{array}$} & \multicolumn{3}{|c|}{ t-test for Equality of Means } \\
\hline & & & & & & & $\mathrm{F}$ & Sig. & $\mathrm{t}$ & df & $\begin{array}{c}\text { Sig. } \\
\text { (2-tailed) }\end{array}$ \\
\hline \multirow{14}{*}{ Conv. } & \multirow{2}{*}{ OCM1 } & Younger & 50 & 4.28000 & 1.757859 & .248599 & \multirow[t]{2}{*}{.434} & \multirow[t]{2}{*}{.511} & -.568 & 109 & .571 \\
\hline & & Older & 61 & 4.47541 & 1.839343 & .235504 & & & -.571 & 106.418 & .569 \\
\hline & \multirow{2}{*}{ OCM2 } & Younger & 50 & 5.19333 & 1.607931 & .227396 & \multirow[t]{2}{*}{.021} & \multirow[t]{2}{*}{.886} & -.806 & 109 & .422 \\
\hline & & Older & 61 & 5.43169 & 1.502275 & .192347 & & & -.800 & 101.689 & .425 \\
\hline & \multirow{2}{*}{ OCM3 } & Yanger & 50 & 3.24000 & 1.486203 & .210181 & \multirow[t]{2}{*}{3.536} & \multirow[t]{2}{*}{.063} & -1.574 & 109 & .118 \\
\hline & & Older & 61 & 3.73224 & 1.754169 & .224598 & & & -1.600 & 108.868 & .112 \\
\hline & \multirow{2}{*}{ TW1 } & Younger & 50 & 4.93333 & 1.664625 & .235413 & \multirow[t]{2}{*}{.054} & \multirow[t]{2}{*}{.817} & .394 & 109 & .695 \\
\hline & & Older & 61 & 4.80874 & 1.653794 & .211747 & & & .393 & 104.499 & .695 \\
\hline & \multirow{2}{*}{ TW2 } & Younger & 50 & 3.74000 & 1.697390 & .240047 & \multirow[t]{2}{*}{.792} & \multirow[t]{2}{*}{.375} & -.496 & 109 & .621 \\
\hline & & Older & 61 & 3.90710 & 1.817743 & .232738 & & & -.500 & 107.119 & .618 \\
\hline & \multirow{2}{*}{ TW3 } & Younger & 50 & 4.82000 & 1.550671 & .219298 & \multirow[t]{2}{*}{.153} & \multirow[t]{2}{*}{.697} & .548 & 109 & .585 \\
\hline & & Older & 61 & 4.66120 & 1.495043 & .191421 & & & .546 & 103.191 & .587 \\
\hline & TW & Younger & 50 & 3.74667 & 1.716348 & .242728 & .271 & .603 & .713 & 109 & .477 \\
\hline & TW4 & Older & 61 & 3.50820 & 1.783262 & .228323 & & & .716 & 106.184 & .476 \\
\hline & & Younger & 93 & 4.73477 & 1.659811 & .172114 & .843 & .360 & -1.718 & 152 & .088 \\
\hline & OCMI & Older & 61 & 5.18579 & 1.486388 & .190313 & & & -1.758 & 138.055 & .081 \\
\hline & & Younger & 93 & 5.09319 & 1.478808 & .153345 & .295 & .588 & -1.425 & 152 & .156 \\
\hline & OCM2 & Older & 61 & 5.43169 & 1.382891 & .177061 & & & -1.445 & 134.437 & .151 \\
\hline & C & Younger & 93 & 3.24014 & 1.475538 & .153006 & 2.272 & .134 & -1.133 & 152 & .259 \\
\hline & ОСМЗ & Older & 61 & 3.52459 & 1.594503 & .204155 & & & -1.115 & 121.361 & .267 \\
\hline & & Younger & 93 & 5.34050 & 1.475221 & .152973 & 1.508 & .221 & -1.193 & 152 & .235 \\
\hline Rem. & TW1 & Older & 61 & 5.61749 & 1.302186 & .166728 & & & -1.224 & 139.202 & .223 \\
\hline & & Younger & 93 & 3.83871 & 1.893679 & .196365 & .277 & .599 & -2.664 & 152 & .009 \\
\hline & TW2 & Older & 61 & 4.68852 & 1.999879 & .256058 & & & -2.634 & 123.473 & .010 \\
\hline & TW3 & Younger & 93 & 4.96416 & 1.533414 & .159008 & 2.964 & .087 & -1.597 & 152 & .112 \\
\hline & TW 3 & Older & 61 & 5.34426 & 1.296673 & .166022 & & & -1.653 & 142.411 & .100 \\
\hline & TW & Younger & 93 & 4.05735 & 1.886017 & .195571 & .146 & .703 & -1.823 & 152 & .070 \\
\hline & TW4 & Older & 61 & 4.62295 & 1.878214 & .240481 & & & -1.825 & 128.852 & .070 \\
\hline
\end{tabular}


Table 6: T-test for younger respondents employed conventionally and remotely, and for older respondents employed conventionally and remotely

\begin{tabular}{|c|c|c|c|c|c|c|c|c|c|c|c|}
\hline \multirow[t]{2}{*}{ Age } & \multirow[t]{2}{*}{ Dim. } & \multirow{2}{*}{$\begin{array}{l}\text { Type } \\
\text { of } \\
\text { empl. }\end{array}$} & \multirow[t]{2}{*}{$\mathrm{N}$} & \multirow[t]{2}{*}{ Mean } & \multirow{2}{*}{$\begin{array}{c}\text { Std. } \\
\text { Deviation }\end{array}$} & \multirow{2}{*}{$\begin{array}{l}\text { Std. Error } \\
\text { Mean }\end{array}$} & \multicolumn{2}{|c|}{$\begin{array}{c}\text { Levene's Test } \\
\text { for Equality of } \\
\text { Variances }\end{array}$} & \multicolumn{3}{|c|}{ t-test for Equality of Means } \\
\hline & & & & & & & $\mathrm{F}$ & Sig. & $\mathrm{t}$ & df & $\begin{array}{c}\text { Sig. } \\
\text { (2-tailed) }\end{array}$ \\
\hline \multirow{14}{*}{ Younger } & \multirow{2}{*}{ OCM1 } & Convent. & 50 & 4.28000 & 1.757859 & .248599 & \multirow[t]{2}{*}{.304} & \multirow[t]{2}{*}{.582} & -1.530 & 141 & .128 \\
\hline & & Remotely & 93 & 4.73477 & 1.659811 & .172114 & & & -1.504 & 95.541 & .136 \\
\hline & \multirow{2}{*}{ OCM2 } & Convent. & 50 & 5.19333 & 1.607931 & .227396 & \multirow[t]{2}{*}{.249} & \multirow[t]{2}{*}{619} & .374 & 141 & .709 \\
\hline & & Remotely & 93 & 5.09319 & 1.478808 & .153345 & & & .365 & 93.410 & .716 \\
\hline & \multirow{2}{*}{ OCM3 } & Convent. & 50 & 3.24000 & 1.486203 & .210181 & \multirow[t]{2}{*}{.003} & \multirow[t]{2}{*}{.957} & .000 & 141 & 1.000 \\
\hline & & Remotely & 93 & 3.24014 & 1.475538 & .153006 & & & .000 & 99.772 & 1.000 \\
\hline & \multirow{2}{*}{ TW1 } & Convent. & 50 & 4.93333 & 1.664625 & .235413 & \multirow[t]{2}{*}{1.043} & \multirow[t]{2}{*}{.309} & -1.504 & 141 & .135 \\
\hline & & Remotely & 93 & 5.34050 & 1.475221 & .152973 & & & -1.450 & 90.521 & .150 \\
\hline & \multirow{2}{*}{ TW2 } & Convent. & 50 & 3.74000 & 1.697390 & .240047 & \multirow[t]{2}{*}{1.249} & \multirow[t]{2}{*}{.266} & -.308 & 141 & .759 \\
\hline & & Remotely & 93 & 3.83871 & 1.893679 & .196365 & & & -.318 & 110.231 & .751 \\
\hline & \multirow{2}{*}{ TW3 } & Convent. & 50 & 4.82000 & 1.550671 & .219298 & \multirow[t]{2}{*}{.217} & \multirow[t]{2}{*}{.642} & -.534 & 141 & .594 \\
\hline & & Remotely & 93 & 4.96416 & 1.533414 & .159008 & & & -.532 & 99.428 & .596 \\
\hline & & Convent. & 50 & 3.74667 & 1.716348 & .242728 & 1.229 & .269 & -.969 & 141 & .334 \\
\hline & $1 W 4$ & Remotely & 93 & 4.05735 & 1.886017 & .195571 & & & -.997 & 108.840 & .321 \\
\hline & OCM1 & Convent. & 61 & 4.47541 & 1.839343 & .235504 & 4.731 & .032 & -2.346 & 120 & .021 \\
\hline & UCini & Remotely & 61 & 5.18579 & 1.486388 & .190313 & & & -2.346 & 114.936 & .021 \\
\hline & ОСМ2 & Convent. & 61 & 5.43169 & 1.502275 & .192347 & .769 & .382 & .000 & 120 & 1.000 \\
\hline & UCIIL & Remotely & 61 & 5.43169 & 1.382891 & .177061 & & & .000 & 119.187 & 1.000 \\
\hline & & Convent. & 61 & 3.73224 & 1.754169 & .224598 & .530 & .468 & .684 & 120 & .495 \\
\hline & UCM13 & Remotely & 61 & 3.52459 & 1.594503 & .204155 & & & .684 & 118.923 & .495 \\
\hline & TW1 & Convent. & 61 & 4.80874 & 1.653794 & .211747 & 5.925 & .016 & -3.001 & 120 & .003 \\
\hline Older & TWI & Remotely & 61 & 5.61749 & 1.302186 & .166728 & & & -3.001 & 113.741 & .003 \\
\hline & TW2 & Convent. & 61 & 3.90710 & 1.817743 & .232738 & .497 & .482 & -2.258 & 120 & .026 \\
\hline & $1 \mathrm{Wz}$ & Remotely & 61 & 4.68852 & 1.999879 & .256058 & & & -2.258 & 118.922 & .026 \\
\hline & TW3 & Convent. & 61 & 4.66120 & 1.495043 & .191421 & 2.973 & .087 & -2.696 & 120 & .008 \\
\hline & IW3 & Remotely & 61 & 5.34426 & 1.296673 & .166022 & & & -2.696 & 117.648 & .008 \\
\hline & & Convent. & 61 & 3.50820 & 1.783262 & .228323 & .030 & .862 & -3.362 & 120 & .001 \\
\hline & TW4 & Remotely & 61 & 4.62295 & 1.878214 & .240481 & & & -3.362 & 119.678 & .001 \\
\hline
\end{tabular}

\section{DISCUSSION}

\section{Discussion of the results of t-test for conventionally employed and teleworkers}

The results of the t-test for conventionally employed and teleworkers (Table 2) show that, for teleworkers, the four dimensions have statistically significantly higher average values than for conventionally employed workers. These dimensions are: OCM1 - Organizational identification, TW1 - Faith in intentions of Peers, TW3 - Confidence in actions of Peers and TW4 Confidence in actions of Management. Based on this, it can be concluded that hypothesis $\mathrm{H} 1$ is confirmed. Such results are in line with the results of most existing research regarding the organizational commitment of teleworkers (Gainey, Kelley, \& Hill, 1999; Madsen, 2011; Pratt, 1999), and job trust in organizations dominated by teleworking, (Dimitrova, 2003; Hoch, Kozlowski, 2014).

Remote employees are prouder of their company and more strongly feel as being a part of the company. Also, teleworkers have greater confidence in the intentions and abilities of their associates, as well as the efficiency of management. Such results may come as a surprise, and the possible explanation is as follows. In organizations that employ teleworkers, individuals' tasks and deadlines for completing those appear to be better and more clearly defined. It is not possible for employees to complain in person, to express their dissatisfaction and objections to tasks, to delay the start of work, etc. All this contributes to the tasks being performed more efficiently and with greater reliability. When everyone does what they need to do, appropriately and at the intended time, then confidence in coworkers develops. The overall effectiveness and efficiency of the work, as well as the clarity of the established relationships, make the development of stronger confidence in the actions of the management. Remote employees are aware of such relationships, and this obviously suits them. In such circumstances, remote employees are more strongly identified with their company. In the reference (Kowalski, \& Swanson, 2005), a similar result was obtained: clear communication, clear work procedures and tasks lead to increased 
confidence in the management of the organization among remote employees.

Conventionally employed, on the other hand, seem to have more opportunity to be convinced of their shortcomings and imperfections, both on a professional and human level, through direct and daily contact with associates. In addition, intense interpersonal relationships are developed in conventional organizations, which in some cases can lead to the relaxation of individuals and, subsequently, their effectiveness. Management actions are viewed "first-hand", they are directly felt as well as the style of work, not only the results, and consequently all errors and omissions are more clearly perceived. The visibility of imperfections in the work of management and associates, as well as the imperfections of interpersonal relationships, leads to more opportunities for disappointment for conventionally employed. In conventional companies reality can be harder to hide and beautify. As a result, conventionally employed are more likely to lose their illusions about their organization, less proud of their organization, less likely to feel that they are part of a business, which in fact means a lower level of organizational identification.

For the TW2 - Faith in intentions of Management dimension, these differences are not statistically significant. Remote employees may see the results of their management work, but may not know the real intentions to that extent. It should also be noted that there are no statistically significant differences in the average values of dimensions OCM2 - Organizational involvement and OCM3 Organizational loyalty, for conventionally employed and remote employees. The degree of willingness to work for your business, as well as the degree of loyalty to your business, does not seem to depend on the way you work (conventionally and remotely).

\section{Discussion of the results of $t$-test for control variable Gender}

The results of the t-test for conventionally employed men and conventionally employed women (upper part of Table 3) show that, between conventionally employed men and conventionally employed women, there are no statistically significant differences in the average values of organizational commitment dimensions and trust at work dimensions. Based on this, it can be concluded that hypothesis $\mathrm{H} 2$ has not been confirmed.

The results of the t-test for teleworking men and teleworking women (bottom of Table 3) show that, for female teleworkers, one dimension has a statistically significantly higher average value than for male teleworkers. This dimension is: OCM3 Organizational Loyalty. Thus, female teleworkers exhibit statistically significantly greater organizational loyalty than male teleworkers. Young people working remotely have a very low level of organizational loyalty and will easily change their organization if given a better opportunity. This finding is consistent with the finding of a reference (De Lay, 1995), according to which men have a lower degree of organizational commitment. Women working remotely are obviously more satisfied and would not change jobs so easily. Long-distance jobs give women the opportunity to stay at home frequently and carry out various family responsibilities. They appreciate it and are not so willing to risk the change, even if it involves higher salary. Similar observations exist in papers, (Ellison, 1999; Pratt, 1999). Based on this, it can be concluded that hypothesis $\mathrm{H} 3$ is partially confirmed.

The results of the t-test for males conventionally employed and male teleworkers (upper part of Table 4) show that, for males conventionally employed, one dimension has a statistically significantly higher average value than for male teleworkers. This dimension is: OCM3 Organizational Loyalty. Thus, males conventionally employed exhibit statistically significantly greater organizational loyalty than male remote employees. The previous statement is repeated once more: young people working remotely have a very low level of organizational loyalty and will easily change their organization if given a better opportunity. Male conventionally employed people are more attached to the organization in which they work, they will find it harder to change jobs, even if another organization offers them a higher salary. Based on this, it can be concluded that hypothesis $\mathrm{H} 4$ is partially confirmed.

The results of the t-test for females conventionally employed and female teleworkers (bottom of Table 4) show that, for female teleworkers, even five dimensions have statistically significantly higher average values than females that are conventionally employed. These dimensions are: 
OCM1 - Organizational identification, TW1 - Faith in the intentions of Peers, TW2 - Faith in the intentions of Management, TW3 - Confidence in actions of Peers and TW4 - Confidence in actions of Management. The explanations given for the full-sample t-test (for conventionally employed and teleworkers) apply here. Obviously, these explanations are particularly expressed in women (females conventionally and remotely employed). Based on this, it can be concluded that hypothesis H5 is confirmed. Existing research, for example (Mokhtarian, Bagley, \& Salomon, 1998; Pratt, 1999), also shows that women have greater motivation to work remotely, and thus a higher level of organizational commitment and trust.

\section{Discussion of the results of t-test for control variable Age}

The results of the t-test for conventionally employed younger respondents and conventionally employed older respondents (upper part of Table 5) show that, between conventionally employed younger respondents and conventionally employed older respondents, there are no statistically significant differences in average organizational commitment dimensions and trust at work dimensions. Based on this, it can be concluded that hypothesis H6 has not been confirmed.

The results of the t-test for teleworkers of younger respondents and teleworkers of older respondents (bottom of Table 5) show that, in older teleworkers, one dimension has a statistically significantly higher average value than in younger teleworkers. This dimension is: TW2 - Faith and intentions of Management. Thus, older respondents employed remotely exhibit statistically significantly greater confidence in management intentions than younger respondents employed remotely. It should be noted here that older remote employees have a significantly higher (though not statistically significantly higher) average score for dimension TW4 - Confidence in actions of Management. When older respondents have faith in management actions, they can more easily and clearly identify the link between effective management actions and good management intentions, thanks to their experience. Therefore, due to their work experience, they consider that good actions are inseparable from good intentions. In addition, it is possible that older respondents pay more attention to the results and then their intentions are not so important: as soon as the results of the management are good, they are satisfied with their safety and consider that the management's intentions are also good. Based on this, it can be concluded that hypothesis $\mathrm{H} 3$ is partially confirmed.

Results of the t-test for younger respondents conventionally employed and younger respondents employed remotely (upper part of Table 6) show that, between younger respondents conventionally employed and younger respondents employed remotely, there are no statistically significant differences in the average values of organizational commitment dimensions and trust at work dimensions. Based on this, it can be concluded that hypothesis $\mathrm{H} 8$ has not been confirmed.

The results of the t-test for older conventionally employed and older remotely employed (bottom of Table 6) show that, for older remote employees, even five dimensions have statistically significantly higher average values than older conventional workers. These dimensions are: OCM1 - Organizational identification, TW1 - Faith in intentions of Peers, TW2 - Faith in intentions of Management, TW3 - Confidence in actions of Peers and TW4 - Confidence in actions of Management. The explanations given for the fullsample t-test (conventionally employed and teleworkers) apply here. Obviously, these explanations are especially shown in older respondents (older conventionally employed and older employed remotely). Based on this, it can be concluded that hypothesis H9 is confirmed.

\section{CONCLUSION}

Remote employees exhibit a stronger organizational commitment and trust at work than conventional employees. This applies to the following four dimensions: OCM1 Organizational identification, TW1 - Faith in intentions of Peers, TW3 - Confidence in actions of Peers and TW4 - Confidence in actions of Management. Remote employees highly appreciate the certainty of precisely defined tasks and deadlines, while conventional employees are directly exposed to real-world conditions, which make it easier to notice any gaps in peers and management. As a result, remote employees have greater confidence in their associates, then in management, and finally, this leads to enhanced organizational identification. These differences, as well as the explanations given, are particularly noticeable for women (females conventionally employed and female teleworkers) and older 
respondents (older respondents conventionally employed and older teleworkers).

For OCM2 dimensions - Organizational involvement and OCM3 - Organizational loyalty, there is no statistically significant difference in average values for conventionally employed and teleworkers: generally, at the overall sample level, the degree of engagement at work, as well as the degree of loyalty to the organization, do not depend on type of employment (conventional and remote).

Inclusion in the analysis of the Gender control variable revealed the following: female teleworkers exhibit statistically significantly greater organizational loyalty than male teleworkers; males conventionally employed exhibit statistically significantly greater organizational loyalty than male remote employees. Therefore, male teleworkers have a very low level of organizational loyalty and it will not be a problem for them to leave their current job if they are offered a better offer in another organization.

Inclusion in the analysis of the Age control variable revealed the following: older teleworkers exhibit statistically significantly greater confidence in management intentions than younger teleworkers. Older respondents employed remotely also have a significantly higher confidence in management actions (this difference is not statistically significant). Older respondents, based on experience, perceive a bond of good actions and good intentions. They also, for the sake of their safety, value the good results of management more, and in that case the management's intentions (for them) are good or at least acceptable.

The results showed that work (conventional and remote) has an impact on organizational commitment and trust at work. The direction of this impact is in line with most existing research. The main limitation of this research is that it was conducted in Serbia (for the most part), so the results obtained are primarily valid for teleworking in organizations in Serbia.

Leaders and managers in conventional organizations, in particular, should be aware of the potential for employees to experience a decline in organizational identification and confidence in peers and managers. In order to overcome these problems, it is necessary to issue precisely defined tasks, with clear and feasible deadlines. Also, in conventional organizations, it is necessary to improve the strategic functioning of management, but also to continuously work on establishing and developing good interpersonal relationships. All this will contribute to greater confidence at work and then to greater organizational identification of employees. Organizations practicing teleworking should strengthen the system of clearly defined duties and deadlines, but they must take into account that male teleworkers have low organizational loyalty and can easily leave their current job.

\section{REFERENCES}

Bernardino, A.T. (1996). Telecommuting: Modeling the employer's and the employee's decisionmaking process. New York: Garland Publishing.

Bowen, T., \& Pennaforte, A. (2017). The Impact of Digital Communication Technologies and New Remote-Working Cultures on the Socialization and Work-Readiness of Individuals in WIL Programs. Work-Integrated Learning in the 21st Century (International Perspectives on Education and Society, Vol. 32), Emerald Publishing Limited, 99. 112.

Cook, J., \& Wall, T. (1980). New Work Attitude Measures of Trust, Organizational Commitment and Personal Need Non-Fulfilment. Journal of Occupational Psychology, 53, 39-52.

Coveyduck, D. H. (1997). Investigation of selected factors on job satisfaction among telecommuters (Master's Thesis, Carleton University, 1997). ProQuest Digital Dissertation, AAT MQ22069.

De Lay, N.L. (1995). The effects of telecommuting and gender on work-family conflict and satisfaction. Doctoral dissertation, Chicago: Illinois Institute of Technology.

de Vries, H., Tummers, L., \& Bekkers, V. (2018). The Benefits of Teleworking in the Public Sector: Reality or Rhetoric? Review of Public Personnel Administration, 39(4), 570-593.

Dimitrova, D. (2003). Controlling teleworkers: supervision and flexibility revisited. New Technology, Work \& Employment, 18(3), 181-195.

Ellison, N.B. (1999). Social impacts: New perspectives on telework. Social Science Computer Review, 17(3), 338-356.

Erricheiello, L., \& Pianesse, T. (2019). Smart Work Centers as "Creative Workspaces" for Remote Employees. CERN IdeaSquare Journal of Experimental Innovation, 2(1), 14-21.

Gainey, T.W., Kelley, D.E., \& Hill, J.A. (1999). Telecommuting's impact on corporate culture and individual workers: Examining the effect of employee isolation. SAM Advanced Management Journal, 64(4), 4-10. 
Hoch, J.E., \& Kozlowski, S.W. (2014). Leading virtual teams: Hierarchical leadership, structural supports, and shared team leadership. The Journal of Applied Psychology, 99, 390-403.

Janićijević, N. (2008). Organizational behavior, Belgrade: Data Status. (in Serbian)

Kowalski, B.K., \& Swanson, J.A. (2005). Critical success factors in developing teleworking programs. Benchmarking: An international Journal, 12(3), 236-249.

Lister, K., Harnish, T., \& Nilles, J.M. (2009). Undress for success: the naked truth about making money at home. Hoboken, NJ: John Wiley \& Sons.

Madsen, S.R. (2011). The benefits, challenges, and implication of teleworking: a literature review. Journal of Culture and Religion, 1(1), 148-158.

Mokhtarian, P.L., Bagley, M.N., \& Salomon, I. (1998). The impact of gender, occupation, and presence of children on telecommuting motivations and constraints. Journal of the American Society for Information Science, 49(12), 1115-1134.

Morgan, R.E. (2004). Teleworking: an assessment of the benefits and challenges. European Business Review, 16(4), 344-357.
Pratt, J.H. (1999). Cost / benefits of teleworking to manage work / life responsibilities. 1999 Telework America National Telework Survey for The International Telework Association \& Council.

Robbins, S.P., \& Judge, T.A. (2009). Organizational behavior, 12th Edition, Zagreb: Mate d.o.o. (in Croatian)

Ross, K.A. (1990). Personality and work style characteristics of the telecommuter (Master's Thesis, San Jose State University, 1990). ProQuest Digital Dissertation, AAT 1341696.

Twentyman, J. (2010). The flexible workforce. The Times, 21 September 2010, 1-16.

Wheatley, D. (2012). Good to be home? Time use and satisfaction levels among home-based teleworkers. New Technology, Work \& Employment, 27(3), 224241.

White, P. (2018). Do remote employees prefer different types of appreciation than employees in face-to-face settings? Strategic HR Review, 17(3), 137-142.

\section{ORGANIZACIONA POSVEĆENOST I POVERENJE ZAPOSLENIH NA DALJINU}

Ovaj rad ispituje i analizira razlike u organizacionoj posvećenosti i poverenju na poslu između klasično zaposlenih i zaposlenih na daljinu. Dve dodatne kontrolne varijable su uvedene u istraživanje: Pol i starost ispitanika . Istraživanje je obuhvatilo 265 ispitanika zaposlenih u organizacijama u Srbiji $(\mathbf{8 8 , 3 \%})$ i okolnim zemljama (Bosna i Hercegovina, Crna Gora, Hrvatska). Udaljeni zaposleni pokazuju jaču organizacijsku posvećenost i poverenje u posao od klasi čnih zaposlenih. Ovo se odnosi na sledeće četiri dimenzije : organizaciona identifikacija, vera u namere vršnjaka, poverenje u postupke vršnjaka i poverenje u akcije menadžmenta. Istovremeno, ukupni uzorak pokazuje da stepen angažovanosti na poslu, kao i stepen lojalnosti organizaciji, ne zavisi od načina rada (konvencionalno ili na daljinu ). Međutim, muški radnici imaju vrlo nizak nivo organizacione lojalnosti i neće im biti problem da napuste svoj trenutni posao ako im se ponudi bolji položaj u nekoj drugoj organizaciji. Stariji radnici na daljinu pokazuju statistički značajno veće poverenje u namere menadžmenta od mlađih radnika. Lideri i rukovodioci u konvencionalnim organizacijama treba da budu svesni potencijala da zaposleni dožive pad u organizacijskoj identifikaciji i poverenju u vršnjake i menadžere. Organizacije koje upražnjavaju rad na daljinu moraju osigurati da muški radnici imaju nisku organizacionu lojalnost i da mogu lako napustiti svoj trenutni posao.

Ključne reči: Organizaciona posvećenost; Poverenje na poslu; Zaposleni; Pol; Starost. 